\title{
CORRECTION OF PHYSICAL EDUCATION PROGRAM FOR TECHNICAL HIGHER EDUCATIONAL ESTABLISHMENT GIRL-STUDENTS ON THE BASE OF THEIR HEALTH INDICATORS
}

Kolumbet A.N., Dudorova L.Yu.

Kiev National University of Technology and Design

\begin{abstract}
Purpose: to illustrate opportunities of physical education in health strengthening of technical HEE girlstudents through correction of their biological age components. Material: 127 girl-students participated in the research. Results: the authors' program of biological age correction permitted to increase breathing pauses, hand strength, time of static balance and reduce blood pressure. Knowledge of biological age and mechanisms of too early ageing facilitates practicing healthy life style and formation of body-motor conditions. We offered trainings of biological age correction' methodic, oriented on prophylaxis of organism's ageing, reduction of biological age and prolongation girl-students' active life. Conclusions: specially determined biological age of an individual can be used as integral characteristic of his/her health condition.
\end{abstract}

Key words: physical, education, biological, age, health, girl-students.

\section{Introduction}

The problem of health protection and strengthening is one of main tasks of our society. Modern conditions of education in higher educational establishments set high requirements to students' health. Absence of healthy life style and low motor activity condition sharply accelerated ageing, characteristic for all age groups. It reflects general tendency to worsening life quality, health and physical fitness. Besides it determines the demand in prophylaxis of too early ageing and working out health related technologies.

To day actually every forth patient and fifth citizen of workable age have diseases of cardio-vascular system, [22, 41, 50]. Vegetovascular dystonia is one of the most frequent cardio-vascular diseases among young persons. With it among women it is 2-3 times more frequent than among men [1, 25, 43, 46].

Recent scientific researches witness that in health rehabilitation and strengthening active role is played by complexes of rehabilitation measures. Such complexes are directed at treatment of existing pathological; syndromes and improvement of students' health. Physical education means engage important place in these complexes that is proved by scientific works [10, 18, 26, 53]. Systemic physical exercises' practicing facilitates significant strengthening of students' organism's resistance and physical fitness [34, 42, 47, 51]. With it harmony of he whole organism is achieved.

Compliance of students' individual morphological functional level with mean statistic standard of this population reflects non-uniformity of development, maturity and ageing of different physiological systems. The temp of organism's adaptation potentials' age changes determines such model conception as biological age [11, $32,44,48]$. Biological age is an indicator of wear out of structure and organism's definite structural element or group of elements and organism in the whole, expressed in units of time. It is found by correlating the measured individual bio-markers with reference mean population curves of these bio-markers' dependences on calendar age $[5,8,11,17]$.

It is known that mean biological age of Ukrainians is much higher than in their European peers. This age is nearly equal to Africans' age $[6,30,37,38]$. Comparing with Europe, in Ukraine youth more frequent has diseases $[4,9,35]$.

The problem of too early ageing is relevant due to its biological and economic consequences. It is known that early ageing significantly influences on period of working and creative activity. In Ukraine this indicator is 30 years (in the range of age from 20-25 - to 50-55 years). In poorer countries it lasts 45-50 years $[2,12,31,36]$.

If to analyze literature sources chronologically it is seen that interest to too early ageing was manifested by many authors. In modern literature the problem of students' biological and passport age correlation is regarded in the works of many authors $[3,13,20,23]$. In these works it is pointed that students' biological age is, in average,

(c) Kolumbet A.N., Dudorova L.Yu., 2016 doi:10.15561/20755279.2016.0602 
from 40 to 46 years, Discrepancy between biological and passport age is from 10 to 40 years. Approximately $15-$ 20 years ago this difference was $4-5$ years $[14,27,39,45]$.

In scientific works significance of biological and passport age coincidence is noted. If biological age of heart is much higher than passport age there appears a risk of cardio-vascular system's disease and too early heart's ageing $[16,24,40,52]$.

From medical sources it is known that every person's organism ages hetero-chronically. In different life periods, ageing of people from different countries and continents is different [19, 29, 33, 49]. In respect to Ukrainians, there is no mentioning of "age strata" with higher ageing temps. Also it is unknown, if ageing temps are equal for men and women in Ukraine. In scientific journals there are very few works, devoted to biological ageing and its correction by physical education means, especially in respect to students.

Hypothesis: it was assumed that partial individualization of girl-students' physical education on the base of data about their health would permit to raise the level of their physical fitness.

The purpose of the research: is to illustrate opportunities of physical education in health strengthening of technical HEE girl-students through correction of their biological age components.

\section{Material and methods}

Participants: in the research 127 1-st $-2^{\text {nd }}$ year girl-students of 17-21 years' age, from Kiev national university of technology and design participated. All girl students were practically healthy (I.e. did not have any health problems). The girl-students were divided into experimental and control groups.

Organization of the research: the research was conducted in 2015-2016. At the beginning of 2015 we registered girl-students' biological age, detected weak organism' systems, worked out individual program of physical education. At the end of 2016 we again registered biological age of the same girl-students. The experiment implied working out means for biological age correction and implementation of the authors' program and methodic in educational process.

For determination of personal biological age we used some modified methods [25]. For biological age assessment we used indicators of separate organism systems' maturity. The assessment was fulfilled by comparing girl-students' appropriate indicators with standards, characteristic for this age group. For correct assessment of biological age it is desirable to use several indicators in heir combination. However, in practice, when doing mass examinations, one has to consider separate indicators, which reflect human state rather satisfactory. Biological age assessment shall reflect clear age changes, which can be measured or described. The method of such changes' assessment shall not be harmful for the health and shall not cause unpleasant feelings. It shall be suitable for screening of great number of girl-students. We used abbreviated method of biological age determination [25]: determination of obesity degree (weight-height indicator); hand power (hand dynamometry); testing of cardiovascular system (heart beats rate -HBR after 20 squats); state of nervous system (Romberg's test); state of respiratory system (vital capacity of lungs - VCL); determination of blood vessels' elasticity (blood pressure); functional state of respiratory and blood circulation systems (Genchi's test).

\section{Statistical analysis:}

For processing of the research's results we used mathematical statistic methods. For every indicator we calculated mean values and mean square deviation. Confidence of results was assessed with Student's t-criterion at $1 \%$ and $5 \%$ significance levels.

In conduct of complex pedagogic and biologic testing of girl-students we observed health protection laws of Ukraine and Helsinki declaration 2000; directive №86/609 of European community on human participation in medical-biological researches.

\section{Results}

Results of preliminary research (2015) showed that girl-students' average biological age (27.9 years) does not correspond to passport age (18.6 years) exceeding it. Accelerated temps of ageing are observed in $99 \%$ girlstudents. Distribution by biological age is not uniform and the rage of variations is 27.0 years. In $17 \%$ girl-students biological age is within from 23 to 26 years; in $10 \%$ from 27 to 30 years; in $31 \%$ - from 31 to 34 years; in $21 \%$ from 35 to 38 years; in $14 \%$ it is from 39 to 50 years; $4 \%$ have biological age from 51 to 60 years; $1 \%$ - from 61 
to 70 years. Thus, biological age of most of girl-students is in the range form 30 to 40 years. The quantity of girl -students with low biological age (18-20 and 20-22) is insignificant and is not obligate (1\% and $1 \%$ accordingly).

By results of preliminary testing in 83 girl-students we registered low health level; in 29 - below average and in 15 girl-students - average level. Thus, the girl-students' health can not be assessed as above average. Therefore, no one of them is in "safe zone". It is connected with deficiency of physical functioning and absence of systemic sports practicing.

Other mean-statistic data of our research are given in table 1.

The youngest biological age was 19.7 years. It exceeds passport age by 1.7 years. It should be noted that it is the best indicator. In all other cases biological age indicators are much worse.

The methodic of biological age assessment did not envisage study of volume and content of motor functioning. That is why we could not analyze influence of the latter on biological age.

Pedagogic experiment implied initial testing of control and experimental groups' girl-students. During academic year experimental group was trained by the authors' program of biological age correction. After finishing pedagogic experiment we received results of finalizing testing of these groups' biological age (see table 1).

Table 1. Girls-students' biological age indicators before and after application the authors' program

\begin{tabular}{lllll}
\hline №No & Indicators & Before experiment & After experiment & Confidence \\
\hline 1 & Weight-height indicator, conv.un. & 21.9 & 22.2 & $\mathrm{P} \geq 0.05$ \\
2 & Static balance (Romberg's test), sec. & 51.4 & 45.6 & $\mathrm{P} \leq 0.05$ \\
3 & Blood pressure, mm.merc.col. & 34.9 & 29.2 & $\mathrm{P} \leq 0.05$ \\
4 & Breath pause (Genchi's test), sec. & 33.5 & 30.3 & $\mathrm{P} \leq 0.05$ \\
5 & Hand dynamometry, kg & 38.5 & 31.7 & $\mathrm{P} \leq 0.05$ \\
6 & VCL, liters & 18.1 & 18.2 & $\mathrm{P} \geq 0.05$ \\
7 & HBR restoration after 20 squats, & 17.8 & 18.2 & $\mathrm{P} \geq 0.05$ \\
& beats per sec. & & & \\
8 & Mean passport age, years & 17.6 & 18.6 & $\mathrm{P} \geq 0.05$ \\
9 & Mean biological age, years & 27.9 & 23.3 & $\mathrm{P} \leq 0.05$ \\
\hline
\end{tabular}

It is undoubted that influence of physical education means on student's organism is extremely necessary. However, to influence on biological age it is required to determine the most significant indicators. With Pearson's method of pair correlation we determined correlation coefficients. The highest rating belonged to indicator of pause after exhale $(\mathrm{r}=0.91)$; the second place is taken by static balancing on one leg with closed eyes $(\mathrm{r}=0.59)$; third place belonged to blood pressure $(\mathrm{r}=0.43)$. All these were considered in selection of the authors' program means.

The worked out authors' program included theoretical part. This part is a cycle of lectures targeted to open main principles and sense of the studies conceptions. The second part included content of practical, methodic and independent trainings. In the process of trainings we practically familiarized girl-students with complex of targeted means, oriented on human biological age correction and on application of the received knowledge in practice. As a result of this part's realization girl-students mastered therapeutic physical culture exercises, vestibular and fine motor exercises, breathing methodic, psycho-correction techniques. Besides, the girl-students knew methods of determination of human biological age and learnt to independently find it by calculations.

Independent trainings by the authors' methodic were directed at better mastering of material. Practical classes were conducted in the process of compulsory academic hours on discipline "Physical education". In our opinion group practical classes shall be conducted with application of individual approach to girl-students. It will permit for them to self-influence by correction and prophylaxis exercises. Means for biological age correction can include: therapeutic physical exercises, breathing exercises and exercises for psycho-correction relaxation $[15,16$, 19].

The repeated testing of biological age showed that in 21\% girl-students it is within from 23 to 26 years; in $16.0 \%$ - from 27 to 30 years; in $32.0 \%$ - from 31 to 34 years; in $17.0 \%$ - from 35 to 38 years; in $10.0 \%$ - from 39 to 50 years and in $1.0 \%$-from 51 to 60 years. The quantity of girl=student with low biological age (18-20 and 2022 ) remained insignificant ( $1 \%$ and $2 \%$ accordingly). The main is: period of breath pause, hand strength and period 
of static balance increases as well as blood pressure reduced (see table 1). With it the following indicators nearly did not change: weight-height indicator, VCL, HBR after 20 squats (restoration of pulse).

As it follows from the received data the authors' program of girl-students' biological age correction and its realization methodic showed their confident effectiveness by most of the tested indicators.

\section{Discussion}

The results of presented here work can be called deplorable: they witness about significant passport age exceeding by biological age. In the future this gap can only increase owing to accelerated ageing. If now biological age is about 28 years, then in the nearest 5 years it can raise up to 40 years. It is necessary to think about control over this process and improvement girl-students' health.

It should also be noted that ageing is a multi-factor process of biologically conditioned objective and subjective factors' influence, which depend on a person [19, 26, 33]. It can be assumed that correction of a number of physical defects is possible with the help of specially selected physical exercises. On the base of the present work we can conclude that one training a week is not enough for health strengthening and improvement. It is necessary to think about independent trainings (for example in sport circles). With it individual condition of girlstudents shall be considered [15, 37, 40].

As a result of the authors' program application we registered that girl-students' heaviest problems appear in respiratory system. By Genchi's test 55.6\% have low health level, 18.5\% - health below average. For cardio vascular and respiratory systems aerobic kinds of sports can be proposed. For example: run or power walking, swimming bicycle racing, dances, skating (roller skating) or skiing, outdoor games with ball (basketball, football, volleyball and etc.) $[15,21,28]$.

Besides, Romberg's test showed the presence of problems with nervous system in girls. Indeed, balancing, as one of coordination qualities, directly influences on professional qualities of technologists and designers [26, 40].

We compared the received data with the data of other authors, who studied this problem earlier. Results of biological age study in the whole coincide with the data of other authors, living in Ukraine.

\section{Conclusions}

1. Specially determined girl-students' biological age can be used as an integral characteristic of their health.

2. As far as human biological age is conditioned by physiological, functional and adaptation organism's potentials, physical education means can be considered to be the most rational mean for ensuring longevity and prevention from too early ageing. They permit to mobilize adaptation mechanisms of young people, who are bent to pathologies of different organism's organs and systems.

3. Knowledge of biological age essence and mechanisms of too early ageing can facilitate the tasks of girlstudents' self-perfection, healthy life style and formation of body-motor conditions; self-correction of organism's systems and functions.

4. Within the frames of "Physical education" discipline in university it is purposeful to realize the course by choice. This course is based on mastering biological age correction methodic; reduction of biological age and prolongation of girl-students' active life.

5. It is purposeful to introduce lectures, methodic and practical classes in the process of physical education in university. Such classes will be mainly directed at future technologists (designers, engineers) preparation for ageing prophylaxis through biological age reduction and active life prolongation.

The prospects of future studies imply development and implementation of too early ageing prophylaxis program for students.

\section{Conflict of interests}

The authors declare that there is no conflict of interests. 


\section{References:}

1. Abbakumov SA, Makolkin VI, Sapozhnikova AA. Nejrocirkuliatornaia distoniia [Neuro-circulatory dystonia], Cheboksary: Chuvashia; 1995. (in Russian)

2. Amosov NM., Bendett MA. Fizicheskaia aktivnost' $i$ serdce [Physical functioning and heart], Kiev: Health; 1989. (in Russian)

3. Anan'ev VA. Psikhologiia zdorov'ia [Psychology of health], Sankt Petersburg: Speech; 2006. (in Russian)

4. Apanasenko GL. Izbrannye stat'i o zdorov'e [Selected papers about health], Kiev; 2005. (in Russian)

5. Akhaladze MG. Ocinka tempu starinnia, stanu zdorov'ia i zhittiezdatnosti liudini na osnovi viznachennia biologichnogo viku. Dokt. Diss. [Assessment of ageing temp, health state and person's vitality on the base of biological age. Dokt. Diss.], Kiev; 2007. (in Ukrainian)

6. Bazhal A. Ukrains'ki khroniki: smertnist' [Ukrainian chronicles: mortality]. Dzerkalo tizhnia, 2010;46:8. (in Ukrainian)

7. Belozerova LM. Metody opredeleniia biologicheskogo vozrasta i umstvennoj i fizicheskoj rabotosposobnosti [Methods of determination of biological age and mental and physical workability], Perm: PGMA; 2000. (in Russian)

8. Bulich EG. Sovremennye dostizheniia nauki o zdorov'e [Modern achievements of science of health]. Teoriia i praktika fizicheskoj kul'tury, 2004;1:62-63. (in Russian)

9. Bushuiev IuV. Riven' fizichnogo zdorov'ia studentiv iak kliniko-fiziologichna osnova fizichnogo vikhovannia u vuzi. Kand. Diss. [Students' physical health level as clinic-physiological base of physical education in HEE. Cand. Diss.], Dnepropetrovsk; 2007. (in Ukrainian)

10. Vojtenko VP. Biologicheskij vozrast [Biological age]. Leningrad: Science; 1982. (in Russian)

11. Vojtenko VP, Tokar AV, Rudaia ES. Metodika opredeleniia biologicheskogo vozrasta [Methodic of biological age determination]. Voprosy gerontologii, 1989;11:9-16. (in Russian)

12. Griban VG. Valeologiia [Valueology], Kiev: Center educational literature; 2005. (in Ukrainian)

13. Zakharina E. The analysis of Classic Private University student's physical health. Pedagogics, psychology, medical-biological problems of physical training and sports, 2009;7:61-63.

14. Zeleniuk OV. Fizicheskoe vospitanie v upravlenii sostoianiem zdorov'ia studencheskoj molodezhi [Physical education in control of students' health]. Fizicheskoe vospitanie studentov tvorcheskikh special'nostej, 2002;2:75-82. (in Russian)

15. Kalinkina OM. Doslidzhennia mozhlivosti vikoristannia pokaznika biologichnogo viku dlia viznachennia vplivu stanu navkolishn'ogo seredovishcha na zdorov'ia liudej [Study of possibility of biological age indicator's usage for determination of environmental conditions' influence on people's health]. VI Mizhnarodna naukova konferenciia "Okhorona navkolishn'ogo seredovishcha ta racional'ne vikoristannia prirodnikh resursiv" [6th International scientific conference "Protection of environment and rational usage of natural resources", Donets'k], Donets'k; 2007. P.134-135. (in Ukrainian)

16. Kishkun AA. Biologicheskij vozrast i starenie [Biological age and ageing], Moscow: GEOTAR Media; 2008. (in Russian)

17. Klapchuk VV, Samoshkin VV. Kil'kisna ocinka rivnia fizichnogo zdorov'ia ta rekreacijno-ozdorovchi rezhimi [Quantitative assessment of physical health level and health related recreational regimes], Dnepropetrovsk: DDIFKIS; 2009. (in Ukrainian)

18. Kopko IIe, Fil' VM. Biologichnij vik iak biomarker diagnostiki rivnia zdorov'ia students'koi molodi [Biological age as bio-marker of students' health]. Naukovo-pedagogichni problemi fizichnoi kul'turi, 2011;13:249-254. (in Ukrainian)

19. Korol SA. Assessment of physical health and physical fitness of students of technical specialties of I course. Pedagogics, psychology, medical-biological problems of physical training and sports, 2014;11:23-29. doi:10.15561/18189172.2014.1105

20. Loshits'ka TI. Biological age and rates of senescence of organism of students. Pedagogics, psychology, medical-biological problems of physical training and sports, 2010;7:50-53.

21. Lugaj MI, Dorogij AP. Zakhvoriuvanist' i smertnist' vid khvorob sistemi krovoobigu v Ukraini [Morbidity and mortality, resulted from blood circulation system's diseases in Ukraine]. Nova medicina, 2002;3:18-21. (in Ukrainian)

22. Mandrikov VB, Salaznikova LV, Miculina MP. O problemakh ocenki funkcional'nogo sostoianiia studentov special'nogo uchebnogo otdeleniia [On problems of assessment of special department students' functional state]. Sovremennye nauchno-metodicheskie razrabotki v fizicheskom vospitanii studentov, imeiushchikh otklonenie v sostoianii zdorov'ia, 2001;1:36-38. (in Russian)

23. Martiniuk O, Pechena V, Kravchenko K. Analiz riznomanitnikh metodik ocinki rivnia fizichnogo zdorov'ia students'koi molodi [Analysis of different assessment methodic for students' physical health]. Fizichna kul'tura, sport ta zdorov'ia nacii, 2014;18(1):183-189. (in Ukrainian) 
24. Pokalev GM. Nejrocirkuliatornaia distoniia [Neuro-circulatory dystonia], N. Novgorod: NSPU; 1994. (in Russian)

25. Prisiazhniuk SI. Biologichnij vik ta zdorov'ia students'koi molodi [Biological age and students' health], Kiev: Center educational literature; 2010. (in Ukrainian)

26. Raevskij RT, Kanishevskij SM. Zdorov'e, zdorovyj obraz zhizni i ozdorovitel'nyj obraz zhizni studentov [Health, healthy life style and health related life style of students], Moscow: Science and Technology; 2008. (in Russian)

27. Romanchishin ON, Sidorko OJ, Dyka MV. Somatic health, adaptable potential, physical condition and biological age of students of pedagogical college. Pedagogics, psychology, medical-biological problems of physical training and sports, 2010;11:98-102.

28. Solov'ev VN. Fizicheskoe zdorov'e kak integral'nyj pokazatel' urovnia adaptacii organizma studentov $\mathrm{k}$ uchebnomu processu [Physical health as integral indicator of students' organism adaptation to educational process]. Fundamental'nye issledovaniia, 2005;6:61-66. (in Russian)

29. Timkiv K. Biologichnij vik ukrainciv [Biological age of Ukrainians]. Korespondent, 2011;46:85. (in Ukrainian)

30. Tserkovna OV, Nefedova AL, Osipov VN, Mirgorod OA. Biological age and rates of ageing at students with different level of impellent activity. Physical Education of Students, 2011;1:130-133.

31. Abar B. Promoting tobacco cessation utilizing pre-health professional students as research associates in the emergency department. Addictive Behaviors, 2015;40(3):73-76.

32. Al-Hariri MT, Al-Hattami AA. Utilization of internet by health colleges students at the University of Dammam. Journal of Taibah University Medical Sciences, 2015;10(1):66-73.

33. Berger H. Mental health of students and its development between 1994 and 2012. Mental Health \& Prevention, 2015;3(1-2):48-56.

34. Dolan E, Hancock E, Wareing A. An evaluation of online learning to teach practical competencies in undergraduate health science students. The Internet and Higher Education, 2015;24(6):21-25.

35. Feuerman VV. Influence of socio-philosophical and spiritual values on the formation of social orientation and physical health specialists the sphere of physical culture and sports. Physical Education of Students, 2014;2:41-45. doi:10.6084/m9.figshare.906859

36. Goginava SE, Rumba OG. On improving effect combining aerobic and anaerobic loads of character in the classroom for physical training in universities. Physical Education of Students, 2014;3:18-29. doi:10.6084/m9.figshare. 974492

37. Golod NR. Principles of developing a well-rounded program of physical rehabilitation for female students in the special medical group with consideration of physical activity impairment. Pedagogics, psychology, medical-biological problems of physical training and sports, 2015;5:9-15. doi:10.15561/18189172.2015.0502

38. Hadden KB. Health literacy training for health professions students. Patient Education and Counseling, 2015;98(7):918-920.

39. Holm-Hadulla RM, Koutsoukou-Argyraki A. Mental health of students in a globalized world: Prevalence of complaints and disorders, methods and effectivity of counseling, structure of mental health services for students. Mental Health \& Prevention, 2015;3(1-2):1-4.

40. Iermakova TS. Development of the idea of forming health culture of a person in the world educational thought. Pedagogics, psychology, medical-biological problems of physical training and sports, 2014;4:8-12. doi:10.6084/m9.figshare.950949

41. Iermakova TS. Education of children in Polish family in a context of forming health culture. Pedagogics, psychology, medical-biological problems of physical training and sports, 2014;11:17-22. doi:10.15561/18189172.2014.1104

42. Iermakova TS. Forming a health culture of future teachers in Polish educational establishments. Physical Education of Students, 2014;5:14-19. doi:10.15561/20755279.2014.0503

43. Iermakova TS. Peculiarities of forming health culture of pupils in Poland: historical aspect. Pedagogics, psychology, medical-biological problems of physical training and sports, 2014;6:16-20. doi:10.6084/m9.figshare. 1004090

44. Kozina ZhL, Kozhuhar LV, Sobko IN, Vaksler MA, Tihonova AA. Workability's recreation methodic with application of cupping massage and autogenic training of women student teams' basketball players. Pedagogics, psychology, medical-biological problems of physical training and sports, 2015;5:16-21. doi:10.15561/18189172.2015.0503

45. Lapkin ST, Levett-Jones C. Gilligan Using the Theory of Planned Behaviour to examine health professional students' behavioural intentions in relation to medication safety and collaborative practice. Nurse Education Today 2015;35(8):935-940.

46. Malenyuk TV, Kosivska AV. Training at sport circle as priority form of organization of students physical 
education (on example of shaping). Pedagogics, psychology, medical-biological problems of physical training and sports, 2015;4:38-42. doi:10.15561/18189172.2015.0407

47. Petrenko NV, Loza TA. Model of recreational and training sessions based on the use of funds aqua professionally applied in the preparation of students of economics. Physical Education of Students, 2014;4:3236. doi:10.6084/m9.figshare.974481

48. Pichurin VV. Psychological and psycho-physical training as a factor of personal anxiety at students. Pedagogics, psychology, medical-biological problems of physical training and sports, 2015;3:46-51. doi:10.15561/18189172.2015.0307

49. Prosvirina LN, Kolokoltsev MM, Kolchanova MA, Cieslicka Miroslawa, Stankiewicz Blazej. The characteristic of the engine qualities of the students of technical institute of III functional health group (special medical group). Physical Education of Students, 2015;1:43-49. doi:10.15561/20755279. 2015.0107

50. Siri A, Rui M. Distance Education for Health Professions' Students. Procedia-Social and Behavioral Sciences, 2015;174;9:730-738.

51. Stanishevska TI, Gorna OI, Berezhniak AS, Horban DD. Daily dynamic of indicators of girl-students' blood micro-circulation. Pedagogics, psychology, medical-biological problems of physical training and sports, 2015;6:23-29. doi:10.15561/ 18189172.2015.0604

52. Usher K et al. Australian health professions student use of social media. Collegian, 2014;21(2):95-101.

53. Yermakova TS. Individualization of forming health culture in schoolchildren of Polish schools. Pedagogics, psychology, medical-biological problems of physical training and sports, 2015;1:29-33. doi:10.15561/18189172.2015.0106 


\section{Information about the authors:}

Kolumbet A.N.; http://orcid.org/0000-0001-8775-4232; re_play@3g.ua; Kiev National University of Technology and Design; st. Nemirovich-Danchenko, 2, Kiev, 14013, Ukraine.

Dudorova L.Yu.; http://orcid.org/0000-0002-6263-4995; vykh46@i.ua; Kiev National University of Technology and Design; st. Nemirovich-Danchenko, 2, Kiev, 14013, Ukraine.

Cite this article as: Kolumbet A.N., Dudorova L.Yu. Correction of physical education program for technical higher educational establishment girl-students on the base of their health indicators. Physical education of students, 2016;6:1825. doi:10.15561/20755279.2016.0602

The electronic version of this article is the complete one and can be found online at: http://www.sportpedu.org.ua/html/arhive-e.html

This is an Open Access article distributed under the terms of the Creative Commons Attribution License, which permits unrestricted use, distribution, and reproduction in any medium, provided the original work is properly cited (http://creativecommons.org/licenses/by/4.0/deed.en).

Received: 21.10.2016

Accepted: 29.11.2016; Published: 28.12.2016 